\title{
A Comparative Study of Iranian EFL Teachers' versus Learners' Perceptions of High School English Textbooks
}

\author{
Zahra Aghazadeh (corresponding author) \\ Department of English Language, Faculty of literature, University of Tabriz, Tabriz, Iran \\ E-mail: Zahra.aghazadeh.zm@gmail.com \\ Parviz Ajideh \\ Department of English Language, Faculty of literature, University of Tabriz, Tabriz, Iran
}

\author{
Doi:10.7575/aiac.alls.v.5n.4p.1 \\ URL: http://dx.doi.org/10.7575/aiac.alls.v.5n.4p.1
}

Received: $13 / 04 / 2014$

Accepted: 29/05/2014

\begin{abstract}
Textbooks play a very crucial role in the process of language teaching and learning. They affect the whole language learning/teaching process. The purpose of this study was to carry out an evaluation of English textbooks currently in use at high schools in Iran from teachers' and learners' points of view in a comparative way. To this end, the study employed a mixed methods design. The data were collected through questionnaires with 43 close-ended items consisting of nine different sections. The results showed that both the teachers and the learners believed that the high school English textbooks are highly ineffective in terms of actual activities, language functions section, pronunciation practice, physical make-up, reading texts, speaking and writing sections and are effective only in terms of vocabulary section, and grammatical points. It can be concluded that the English textbooks used in Iranian high schools cannot meet the Iranian learners' and teachers' needs and wants since they are grammar-based. The findings of this study can be used by the textbook designers in order to take account of the teachers' and learners' preferences and perceptions while designing new editions of the textbooks.
\end{abstract}

Keywords: Textbook, Textbook Evaluation, syllabus design, Perception, EFL Learners, EFL Teachers

\section{Introduction}

Textbook is an almost universal element of English language teaching and no teaching/learning situation is complete until it has its relevant textbook. In educational programs, textbooks are considered to be one of the invaluable components and reliable resource for teaching and learning process. They are important resources for teachers in assisting learners to learn every subject including English. For EFL learners, the textbooks become the major source of contact they have with the language apart from the input provided by the teacher. Moreover, Dubin and Olshtain (1986) state that the tangible element that gives a language course face validity to many teachers and learners, is the textbook. That is why textbook selection and evaluation appears to be a very important issue in teaching and learning process.

\section{Review of the Related Literature}

\subsection{The Importance of Textbooks in Language Learning}

EFL teaching materials are important elements of the curriculum and they are an essential aid for learning which interact with the syllabus, teacher, and learners. Nunan (1991) argues that teaching materials are like flesh on the bones of the course content. Richards and Rogers (1986, as cited in Bahumaid, 2008) believe that even if there is no syllabus for the language course, teaching materials can still fulfill this role. Moreover, since they determine certain parts for the teacher's presentation and others for learner practice and classroom activities, materials can be said to be useful in defining the roles of both teachers and learners (Wright, 1997). Therefore the role and uses of instructional materials in all language programs are significant aspects of language curriculum development. Textbooks are the instructional materials that are widely used in language classrooms. As Davison (1975) states after the teacher, the next most important factor in foreign language classroom are the textbooks. They are considered as an effective resource for selfdirected learning and self-study, an effective resource for presenting materials by the teachers, an effective source of ideas and activities, a reference source for learners, a syllabus that reflects predetermined learning objectives, and support for novice teachers. Moreover, Razmjoo (2007) believes that many learners who work with a textbook feel secure, become more confident, independent and satisfied and have a sense of progress and achievement because they always have a book to relate to, and this textbook provides them with the opportunity to go back and revise whenever they need, to self-study and to use it as a reference tool.

\subsection{Textbook Evaluation}

According to Tomlinson et al. (2001) textbook evaluation is an activity in the field of applied linguistics that enables teachers, supervisors, administrators and materials developers to make judgments about the effect the materials have on the people who use them. Furthermore, Zohrabi (2011) believes that material evaluation should be the top priority of 
any curriculum. Generally speaking, no textbook can be perfect, therefore, textbook evaluation is very important to clarify the suitability of the sources and find the best one.

\subsection{Textbook Evaluation in Iranian Context}

When it comes to teaching English, the textbook issue would be considered as one of the most important topics in countries like Iran in which this language is considered as a foreign one. As a matter of fact, the primary goal of learning English in Iran is to help learners to promote a universal understanding, to become familiar with science, literature, and art of English speaking countries and to find and access sources of information in English (Birjandi \& Soheili, 1982, as cited in Rahimi \& Hassani, 2012). Failing to achieve these goals in Iranian language classes has caused the national EFL curriculum to be carefully scrutinized in order to find the sources of the demotivation of the learners and the reasons behind the failure of language programs in Iran. Through the evaluation of high school textbooks, Yarmohammadi (2002) found that high school textbooks suffer from a number of shortcomings, such as ignoring oral skills and the interchangeable use of English and Persian names. Through the analysis of ten EFL/ESL textbook reviews as well as $10 \mathrm{EFL/ESL}$ textbook evaluation checklists, Ansary and Babaii (2002) provided an outline of the common core features of standard EFL/ESL textbooks, and reached the conclusion that not every textbook would have these features. Jahangard (2007) evaluated four EFL textbooks that are used in the Iranian high schools and are produced the Ministry of Education. He discussed the merits and demerits of the textbooks with reference to 13 common criteria extracted from different materials evaluation checklists. The results of the study indicated that book four had better features in comparison with the three other textbooks (which needed huge revisions and modifications). Rahimpour and Hashemi (2011) had a textbook evaluation study in Iran. They evaluated the three English language textbooks used at high schools all over Iran from the high school English teachers' points of view. The result showed that the textbooks were not satisfactorily acceptable in terms of vocabulary presentation, reading, pronunciation practice, practical concerns, and physical make-up. According to the authors, the textbooks were "to some extent" acceptable in term of grammar presentation and practice. They reached the conclusion that the English language textbooks taught at high schools in Iran do not meet the teachers' expectations. Furthermore, Rahimi and Nabilou (2009) suggest that English textbooks (e.g., level of difficulty, high load of information, too much emphasis on grammar, reading, and vocabulary rather than communication) are one of the sources of the inefficiency of the EFL curriculum in Iran which serve as both the syllabus and main guidelines for English teachers. In 2012, Rahimi and Hassani investigated Iranian high-school learners' attitudes towards their EFL textbooks and its role in their attitudes towards learning English as a foreign language and found that in general learners do not have a positive attitude towards their English language textbooks. Moreover, Textbook evaluation studies in Iran have focused on evaluating language teaching materials from teachers' perspective. The results of such studies attribute the problems with English textbooks to inappropriate content, discrepancy between the content and learning objective, unreasonably high load of information, incomplete explanation for vocabulary, lack of interesting and authentic materials, ignorance of oral skills, ignoring communicative language teaching, and lack of scientific approaches to the teaching of pronunciation (Moradi, 2008, as cited in Rahimi \& Hassani, 2012). In their paper, Farrokhi and Saadi (2013) carried out an evaluation of perceptions of Iranian EFL learners who constitute the users of the first-year high school textbook towards tasks and speech acts and to compare their perceptions with the actual content of their textbooks. The comparison showed that the learners generally rated tasks and the teaching of speech acts as being highly effective in the learning of English, and they rated the language functions section of their textbook to be ineffective in this regard. These findings show that there are wide gaps between the Iranian learners' perceptions and the actual content of their textbooks.

Reviewing the literature disclosed some gaps which were as prompts to conduct this study. To the researcher's best knowledge, no research has been compared the Iranian EFL learners' and the teachers' perceptions regarding the different sections of three high school English textbooks. Therefore, this study aims to evaluate the effectiveness and suitability of the EFL textbooks produced by the Ministry of Education and used in Iranian educational system from teachers' versus learners' points of view in a comparative way. Therefore, the following research question was tackled to be answered in this paper:

Research Question: What are the similarities and differences between the Iranian EFL learners' and teachers' perceptions in terms of the high school English textbooks?

Null Hypothesis: There is no significant difference between Iranian EFL learners' and teachers' perceptions in terms of the high school English textbooks.

Alternative Hypothesis: There is a significant difference between Iranian EFL learners' and teachers' perceptions in terms of the high school English textbooks.

\section{Methodology}

\subsection{Design of the study}

This study employed a mixed methods design, a combination of both qualitative and quantitative dimension of data collection. The use of different data collection methods will lead to deeper insight into the understanding of the phenomenon under investigation.

\subsection{Participants}

3.2.1 Participants of the Questionnaires

A total of 300 female language learners with the age span of 15 to 18 and 50 female English teachers participated in this study. Both groups had a bilingual background of Turkish and Persian. 


\subsubsection{Participants of the Interviews}

The participants for the semi-structured interviews were selected randomly. 2 teachers and 6 learners participated in the interviews.

\subsection{Materials}

The materials used in this study included semi-structured interviews and questionnaires. As a matter of fact, the questionnaires had 5-point scales-in the Likert format and the teachers and the learners were asked to mark their beliefs by ticking one of the five boxes in each elicitation question. The data emerging from ticking one of the 5-point scales were numerical. Hence, they were analyzed quantitatively. The researcher also interviewed some of the teachers and learners in order to cross-check the validity of the results, so the qualitative data were collected through the semistructured interviews. A sample of the questionnaire and a sample of the interview questions are provided in the Appendix A, Appendix B, respectively.

\section{4 edures}

After obtaining the necessary permissions from the Ministry of Education in both Urmia and Salmas and also from the schools and the teachers, the questionnaires were distributed among 300 learners and 50 teachers. To be more specific, the questionnaire disseminated and collected simultaneously in the same day. The same questionnaire was also administered to the teachers at their convenience. The interviews were conducted with 2 teachers and 6 learners. Each interview protocol was carried out face-to-face with the teachers and the learners.

\section{Data analysis \& Results}

In order to answer the research question, descriptive statistics, independent sample t-test were used.

\subsection{Descriptive statistics for Items related to Different Sections of the Book One (Learners' Perceptions)}

The results of the items related to different sections of the first-year high school English textbook in the questionnaire from the learners' perspective are demonstrated in Table 1.

Table 1. Presents the Percentages for Items related to Different Sections of the Book One

\begin{tabular}{|c|c|c|c|c|c|c|c|c|}
\hline & \multicolumn{5}{|c|}{ Learners' Perceptions } & \multicolumn{3}{|c|}{$\begin{array}{c}\text { Merging of the percentages } \\
\text { of the selected options }\end{array}$} \\
\hline & $\mathrm{HE}$ & $\mathrm{SE}$ & NK & SI & $\mathrm{HI}$ & $\mathrm{E}$ & NK & I \\
\hline $\begin{array}{c}\text { Actual activities } \\
(1-5)\end{array}$ & $\begin{array}{l}7 \% \\
(35)\end{array}$ & $\begin{array}{c}6.4 \% \\
(32)\end{array}$ & $\begin{array}{l}6.8 \% \\
(34)\end{array}$ & $\begin{array}{c}28.6 \% \\
(143) \\
\end{array}$ & $\begin{array}{l}51.2 \% \\
(256) \\
\end{array}$ & $13.4 \%$ & $6.8 \%$ & $79.8 \%$ \\
\hline $\begin{array}{l}\text { Language function } \\
(6-10)\end{array}$ & $\begin{array}{l}6.2 \% \\
(31) \\
\end{array}$ & $\begin{array}{c}8.6 \% \\
(43)\end{array}$ & $\begin{array}{c}14.8 \% \\
(74) \\
\end{array}$ & $\begin{array}{c}24.4 \% \\
(122)\end{array}$ & $\begin{array}{l}51.6 \% \\
(258) \\
\end{array}$ & $14.8 \%$ & $14.8 \%$ & $76 \%$ \\
\hline $\begin{array}{c}\text { Reading section } \\
(11-15)\end{array}$ & $\begin{array}{c}16.2 \% \\
(81)\end{array}$ & $\begin{array}{l}20 \% \\
(100) \\
\end{array}$ & $\begin{array}{c}6.8 \% \\
(34) \\
\end{array}$ & $\begin{array}{l}23 \% \\
(115) \\
\end{array}$ & $\begin{array}{l}34 \% \\
(170) \\
\end{array}$ & $36.2 \%$ & $6.8 \%$ & $57 \%$ \\
\hline $\begin{array}{c}\text { Grammatical points } \\
(16-20)\end{array}$ & $\begin{array}{l}25.8 \% \\
(129)\end{array}$ & $\begin{array}{l}26.4 \% \\
(132)\end{array}$ & $\begin{array}{l}9 \% \\
(45) \\
\end{array}$ & $\begin{array}{l}16 \% \\
(80)\end{array}$ & $\begin{array}{l}22.8 \% \\
(114)\end{array}$ & $52.2 \%$ & $9 \%$ & $38.8 \%$ \\
\hline $\begin{array}{c}\text { Vocabulary items } \\
(21-25) \\
\end{array}$ & $\begin{array}{c}28.4 \% \\
(142) \\
\end{array}$ & $\begin{array}{l}41.2 \% \\
(206) \\
\end{array}$ & $\begin{array}{l}6.4 \% \\
(32) \\
\end{array}$ & $\begin{array}{c}9.4 \% \\
(47) \\
\end{array}$ & $\begin{array}{c}14.6 \% \\
(73) \\
\end{array}$ & $69.6 \%$ & $6.4 \%$ & $24 \%$ \\
\hline $\begin{array}{c}\text { Physical make-up } \\
(26-30)\end{array}$ & $\begin{array}{l}7.8 \% \\
(39) \\
\end{array}$ & $\begin{array}{c}10.6 \% \\
(53) \\
\end{array}$ & $\begin{array}{l}7.4 \% \\
(37) \\
\end{array}$ & $\begin{array}{l}28 \% \\
(140) \\
\end{array}$ & $\begin{array}{c}46.2 \% \\
(231) \\
\end{array}$ & $18.4 \%$ & $7.4 \%$ & $74.2 \%$ \\
\hline $\begin{array}{c}\text { Pronunciation } \\
\text { practice(31-34) }\end{array}$ & $\begin{array}{l}8.5 \% \\
(34) \\
\end{array}$ & $\begin{array}{c}13.75 \% \\
(55) \\
\end{array}$ & $\begin{array}{c}9.25 \% \\
(37) \\
\end{array}$ & $\begin{array}{c}25.75 \% \\
(103) \\
\end{array}$ & $\begin{array}{c}42.75 \% \\
(171) \\
\end{array}$ & $\begin{array}{c}22.25 \\
\% \\
\end{array}$ & $9.25 \%$ & $68.5 \%$ \\
\hline $\begin{array}{c}\text { Speaking section } \\
(35-39)\end{array}$ & $\begin{array}{l}5.4 \% \\
(27) \\
\end{array}$ & $\begin{array}{c}6.8 \% \\
(34) \\
\end{array}$ & $\begin{array}{c}4.4 \% \\
(22) \\
\end{array}$ & $\begin{array}{c}27.4 \% \\
(137) \\
\end{array}$ & $\begin{array}{l}56 \% \\
(280) \\
\end{array}$ & $12.2 \%$ & $4.4 \%$ & $83.4 \%$ \\
\hline $\begin{array}{c}\text { Writing section } \\
(40-43)\end{array}$ & $\begin{array}{l}7.5 \% \\
(30) \\
\end{array}$ & $\begin{array}{l}8 \% \\
(32) \\
\end{array}$ & $\begin{array}{l}6.5 \% \\
(26) \\
\end{array}$ & $\begin{array}{c}24.75 \% \\
(99)\end{array}$ & $\begin{array}{c}53.25 \% \\
(213) \\
\end{array}$ & $15.5 \%$ & $6.5 \%$ & $78 \%$ \\
\hline
\end{tabular}

Abbreviations: HE stands for Highly Effective, SE for Somewhat Effective, SI for Somewhat Ineffective, HI for Highly Ineffective, NK for 'I do not know', E for Effective, and I for Ineffective.

The first row of Table 1 presents the percentages of the selected options, and the second row of the Table demonstrates the sum of the number of responses to each of the choices. In the third column of Table 1, the percentages in the second column of the Table have been merged. As Table 1 shows, the learners' responses have a tendency towards the ineffective end of the continuum in terms of Actual activities, Language functions section, Reading section, Physical make-up, Pronunciation practice, Speaking section, and Writing section. However, their responses have a tendency towards the effective end of the continuum in terms of grammatical points and Vocabulary items sections.

\subsection{Descriptive statistics for Items related to Different Sections of the Book Two (Learners' Perceptions)}

The results of the items related to different sections of the second-year high school English textbook in the questionnaire from the learners' perspective are demonstrated in Table 2. 
Table 2. Presents the Percentages for Items related to Different Sections of the Book Two

\begin{tabular}{|c|c|c|c|c|c|c|c|c|}
\hline & \multicolumn{5}{|c|}{ Learners' Perceptions } & \multicolumn{3}{|c|}{$\begin{array}{c}\text { Merging of the percentages } \\
\text { of the selected options }\end{array}$} \\
\hline & $\mathrm{HE}$ & $\mathrm{SE}$ & NK & SI & $\mathrm{HI}$ & $\mathrm{E}$ & NK & $\mathrm{I}$ \\
\hline $\begin{array}{c}\text { Actual activities } \\
(1-5) \\
\end{array}$ & $\begin{array}{l}8.8 \% \\
(44) \\
\end{array}$ & $\begin{array}{c}10.6 \% \\
(53)\end{array}$ & $\begin{array}{l}7.8 \% \\
(39)\end{array}$ & $\begin{array}{l}32.8 \% \\
(164)\end{array}$ & $\begin{array}{l}40 \% \\
(200)\end{array}$ & $19.4 \%$ & $7.8 \%$ & $72.8 \%$ \\
\hline $\begin{array}{l}\text { Language function } \\
(6-10)\end{array}$ & $\begin{array}{c}11.8 \% \\
(59) \\
\end{array}$ & $\begin{array}{c}14.2 \% \\
(71)\end{array}$ & $\begin{array}{c}11.2 \% \\
(56)\end{array}$ & $\begin{array}{l}25.4 \% \\
(127)\end{array}$ & $\begin{array}{l}37.4 \% \\
(187)\end{array}$ & $26 \%$ & $11.2 \%$ & $62.8 \%$ \\
\hline $\begin{array}{c}\text { Reading section } \\
(11-15) \\
\end{array}$ & $\begin{array}{l}17 \% \\
(85) \\
\end{array}$ & $\begin{array}{c}16.8 \% \\
(84) \\
\end{array}$ & $\begin{array}{l}5.4 \% \\
(27) \\
\end{array}$ & $\begin{array}{c}25.8 \% \\
(129) \\
\end{array}$ & $\begin{array}{l}35 \% \\
(175) \\
\end{array}$ & $33.8 \%$ & $5.4 \%$ & $60.8 \%$ \\
\hline $\begin{array}{c}\text { Grammatical points } \\
(16-20)\end{array}$ & $\begin{array}{c}20.2 \% \\
(101) \\
\end{array}$ & $\begin{array}{l}39.4 \% \\
(197) \\
\end{array}$ & $\begin{array}{c}10.4 \% \\
(52)\end{array}$ & $\begin{array}{c}18.2 \% \\
(91) \\
\end{array}$ & $\begin{array}{c}11.8 \% \\
(59)\end{array}$ & $59.6 \%$ & $10.4 \%$ & $30 \%$ \\
\hline $\begin{array}{c}\text { Vocabulary items } \\
(21-25)\end{array}$ & $\begin{array}{l}31 \% \\
(155)\end{array}$ & $\begin{array}{c}36.2 \% \\
(181)\end{array}$ & $\begin{array}{l}9 \% \\
(45) \\
\end{array}$ & $\begin{array}{l}\cdot 14 \% \\
(70) \\
\end{array}$ & $\begin{array}{c}9.8 \% \\
(49) \\
\end{array}$ & $67.2 \%$ & $9 \%$ & $23.8 \%$ \\
\hline $\begin{array}{l}\text { Physical make-up } \\
(26-30)\end{array}$ & $\begin{array}{l}12 \% \\
(60) \\
\end{array}$ & $\begin{array}{c}19.2 \% \\
(96) \\
\end{array}$ & $\begin{array}{c}9.2 \% \\
(46) \\
\end{array}$ & $\begin{array}{c}23.4 \% \\
(117) \\
\end{array}$ & $\begin{array}{c}36.2 \% \\
(181) \\
\end{array}$ & $31.2 \%$ & $9.2 \%$ & $59.6 \%$ \\
\hline $\begin{array}{c}\text { Pronunciation } \\
\text { practice(31-34) }\end{array}$ & $\begin{array}{c}11.25 \% \\
(45)\end{array}$ & $\begin{array}{c}12.75 \\
\% \\
(51) \\
\end{array}$ & $\begin{array}{l}12.75 \% \\
(51)\end{array}$ & $\begin{array}{c}27.75 \% \\
(111)\end{array}$ & $\begin{array}{l}35.5 \% \\
(142)\end{array}$ & $24 \%$ & $\begin{array}{c}12.75 \\
\%\end{array}$ & $63.25 \%$ \\
\hline $\begin{array}{c}\text { Speaking section } \\
(35-39)\end{array}$ & $\begin{array}{l}8.4 \% \\
(42) \\
\end{array}$ & $\begin{array}{c}9.4 \% \\
(47) \\
\end{array}$ & $\begin{array}{l}5.6 \% \\
(28) \\
\end{array}$ & $\begin{array}{c}32.6 \% \\
(163)\end{array}$ & $\begin{array}{l}44 \% \\
(220) \\
\end{array}$ & $17.8 \%$ & $5.6 \%$ & $76.6 \%$ \\
\hline $\begin{array}{c}\text { Writing section } \\
(40-43)\end{array}$ & $\begin{array}{c}13.5 \% \\
(54)\end{array}$ & $\begin{array}{l}16 \% \\
(64)\end{array}$ & $\begin{array}{c}7.75 \% \\
(31) \\
\end{array}$ & $\begin{array}{c}24.25 \% \\
(97)\end{array}$ & $\begin{array}{l}38.5 \% \\
(154)\end{array}$ & $29.5 \%$ & $7.75 \%$ & $62.75 \%$ \\
\hline
\end{tabular}

Abbreviations: HE stands for Highly Effective, SE for Somewhat Effective, SI for Somewhat Ineffective, HI for Highly Ineffective, NK for 'I do not know', E for Effective, and I for Ineffective.

As Table 2 shows, the percentages of the responses rating actual activities, Language functions section, Reading section, Physical make-up, Pronunciation practice, Speaking section, and Writing section to be ineffective are significantly higher than the percentages of those that rated to be effective. However, the percentages of the responses rating grammatical points and Vocabulary items sections to be effective are significantly higher than the percentages of those that rated to be ineffective.

\subsection{Descriptive statistics for Items related to Different Sections of the Book Three (Learners' Perceptions)}

The results of the items related to different sections of the third-year high school English textbook in the questionnaire from the learners' perspective are demonstrated in Table 3.

Table 3. Presents the Percentages for Items related to Different Sections of the Book Three

\begin{tabular}{|c|c|c|c|c|c|c|c|c|}
\hline & \multicolumn{5}{|c|}{ Learners' Perceptions } & \multicolumn{3}{|c|}{$\begin{array}{c}\text { Merging of the percentages } \\
\text { of the selected options }\end{array}$} \\
\hline & $\mathrm{HE}$ & $\mathrm{SE}$ & NK & SI & $\mathrm{HI}$ & $\mathrm{E}$ & NK & I \\
\hline $\begin{array}{c}\text { Actual activities } \\
(1-5)\end{array}$ & $\begin{array}{c}6.6 \% \\
(33)\end{array}$ & $\begin{array}{c}18.8 \% \\
(94)\end{array}$ & $\begin{array}{c}9.2 \% \\
(46)\end{array}$ & $\begin{array}{c}29.6 \% \\
(148)\end{array}$ & $\begin{array}{c}35.8 \% \\
(179)\end{array}$ & $25.4 \%$ & $9.2 \%$ & $65.4 \%$ \\
\hline $\begin{array}{l}\text { Language function } \\
(6-10)\end{array}$ & $\begin{array}{l}6 \% \\
(30) \\
\end{array}$ & $\begin{array}{c}15.8 \% \\
(79) \\
\end{array}$ & $\begin{array}{c}8.6 \% \\
(43) \\
\end{array}$ & $\begin{array}{c}26.8 \% \\
(134)\end{array}$ & $\begin{array}{l}42.8 \% \\
(214)\end{array}$ & $21.8 \%$ & $8.6 \%$ & $69.6 \%$ \\
\hline $\begin{array}{l}\text { Reading section } \\
\qquad(11-15)\end{array}$ & $\begin{array}{c}9.2 \% \\
(46)\end{array}$ & $\begin{array}{c}24.2 \% \\
(121)\end{array}$ & $\begin{array}{c}9.6 \% \\
(48)\end{array}$ & $\begin{array}{c}27.6 \% \\
(138)\end{array}$ & $\begin{array}{c}29.4 \% \\
(147)\end{array}$ & $33.4 \%$ & $9.6 \%$ & $57 \%$ \\
\hline $\begin{array}{c}\text { Grammatical } \\
\text { points }(16-20)\end{array}$ & $\begin{array}{c}24.4 \% \\
(122)\end{array}$ & $\begin{array}{l}31.2 \% \\
(156)\end{array}$ & $\begin{array}{l}7 \% \\
(35)\end{array}$ & $\begin{array}{c}22.6 \% \\
(113)\end{array}$ & $\begin{array}{c}14.8 \% \\
(74)\end{array}$ & $55.6 \%$ & $7 \%$ & $37.4 \%$ \\
\hline $\begin{array}{c}\text { Vocabulary items } \\
(21-25)\end{array}$ & $\begin{array}{l}20 \% \\
(100)\end{array}$ & $\begin{array}{l}41 \% \\
(205)\end{array}$ & $\begin{array}{l}8 \% \\
(40)\end{array}$ & $\begin{array}{c}18.6 \% \\
(93)\end{array}$ & $\begin{array}{c}12.4 \% \\
(62)\end{array}$ & $61 \%$ & $8 \%$ & $31 \%$ \\
\hline $\begin{array}{c}\text { Physical make-up } \\
(26-30)\end{array}$ & $\begin{array}{l}12 \% \\
(60) \\
\end{array}$ & $\begin{array}{c}16.2 \% \\
(81) \\
\end{array}$ & $\begin{array}{c}11.2 \% \\
(56) \\
\end{array}$ & $\begin{array}{c}20.6 \% \\
(103) \\
\end{array}$ & $\begin{array}{l}40 \% \\
(200) \\
\end{array}$ & $28.2 \%$ & $11.2 \%$ & $60.6 \%$ \\
\hline $\begin{array}{c}\text { Pronunciation } \\
\text { practice(31-34) }\end{array}$ & $\begin{array}{l}11 \% \\
(44)\end{array}$ & $\begin{array}{l}17 \% \\
(68) \\
\end{array}$ & $\begin{array}{c}12.5 \% \\
(50)\end{array}$ & $\begin{array}{c}28.75 \% \\
(115) \\
\end{array}$ & $\begin{array}{c}30.75 \% \\
(123)\end{array}$ & $28 \%$ & $12.5 \%$ & $59.5 \%$ \\
\hline $\begin{array}{c}\text { Speaking section } \\
(35-39)\end{array}$ & $\begin{array}{l}5 \% \\
(25) \\
\end{array}$ & $\begin{array}{c}17.2 \% \\
(86) \\
\end{array}$ & $\begin{array}{l}13 \% \\
(65) \\
\end{array}$ & $\begin{array}{c}24.2 \% \\
(121) \\
\end{array}$ & $\begin{array}{l}40.6 \% \\
(203) \\
\end{array}$ & $22.2 \%$ & $13 \%$ & $64.8 \%$ \\
\hline $\begin{array}{c}\text { Writing section } \\
(40-43)\end{array}$ & $\begin{array}{c}9.5 \% \\
(38)\end{array}$ & $\begin{array}{c}18.25 \% \\
(73)\end{array}$ & $\begin{array}{l}9 \% \\
(36)\end{array}$ & $\begin{array}{l}23.75 \% \\
(95)\end{array}$ & $\begin{array}{c}39.5 \% \\
(158)\end{array}$ & $\begin{array}{c}27.75 \\
\%\end{array}$ & $9 \%$ & $\begin{array}{c}63.25 \\
\%\end{array}$ \\
\hline
\end{tabular}

Abbreviations: HE stands for Highly Effective, SE for Somewhat Effective, SI for Somewhat Ineffective, HI for Highly Ineffective, NK for 'I do not know', E for Effective, and I for Ineffective. 
As Table 3 shows, the learners' responses have a tendency towards the ineffective end of the continuum in terms of Actual activities, Language functions section, Reading section, Physical make-up, Pronunciation practice, Speaking section, and Writing section. However, their responses only have a tendency towards the effective end of the continuum in terms of grammatical points and Vocabulary items sections.

\subsection{Descriptive statistics for Items related to Different Sections of the Book One (Teachers' Perception)}

The results of the items related to different sections of the first-year high school English textbook in the questionnaire from the teachers' perspective are demonstrated in Table 4.

Table 4. Presents the Percentages for Items related to Different Sections of the Book One

\begin{tabular}{|c|c|c|c|c|c|c|c|c|}
\hline & \multicolumn{5}{|c|}{ Teachers' Perceptions } & \multicolumn{3}{|c|}{$\begin{array}{l}\text { Merging of the percentages } \\
\text { of the selected options }\end{array}$} \\
\hline & $\mathrm{HE}$ & SE & $\mathrm{NK}$ & SI & $\mathrm{HI}$ & $E$ & NK & I \\
\hline $\begin{array}{l}\text { Actual activities } \\
(1-5)\end{array}$ & $\begin{array}{c}1.6 \% \\
(8)\end{array}$ & $\begin{array}{l}7.4 \% \\
(37)\end{array}$ & $\begin{array}{c}1.8 \% \\
(9)\end{array}$ & $\begin{array}{c}16.8 \% \\
(84)\end{array}$ & $\begin{array}{l}22.4 \% \\
(112)\end{array}$ & $9 \%$ & $1.8 \%$ & $39.2 \%$ \\
\hline $\begin{array}{l}\text { Language function } \\
(6-10)\end{array}$ & $\begin{array}{l}2 \% \\
(10)\end{array}$ & $\begin{array}{c}3.6 \% \\
(18)\end{array}$ & $\begin{array}{c}2.4 \% \\
(12)\end{array}$ & $\begin{array}{c}18.6 \% \\
(93)\end{array}$ & $\begin{array}{l}23.4 \% \\
(117)\end{array}$ & $5.6 \%$ & $2.4 \%$ & $42 \%$ \\
\hline $\begin{array}{l}\text { Reading section } \\
(11-15)\end{array}$ & $\begin{array}{l}5.2 \% \\
(26)\end{array}$ & $\begin{array}{l}8.2 \% \\
(41)\end{array}$ & $\begin{array}{l}2.4 \% \\
(12)\end{array}$ & $\begin{array}{c}16.6 \% \\
(83)\end{array}$ & $\begin{array}{c}17.6 \% \\
(88)\end{array}$ & $13.4 \%$ & $2.4 \%$ & $34.2 \%$ \\
\hline $\begin{array}{c}\text { Grammatical points } \\
(16-20)\end{array}$ & $\begin{array}{c}14.6 \% \\
(73)\end{array}$ & $\begin{array}{c}18.6 \% \\
(93)\end{array}$ & $\begin{array}{l}3 \% \\
(15)\end{array}$ & $\begin{array}{l}6 \% \\
(30)\end{array}$ & $\begin{array}{l}7.8 \% \\
(39)\end{array}$ & $33.2 \%$ & $3 \%$ & $13.8 \%$ \\
\hline $\begin{array}{l}\text { Vocabulary items } \\
\qquad(21-25)\end{array}$ & $\begin{array}{c}13.2 \% \\
(66)\end{array}$ & $\begin{array}{c}18.2 \% \\
(91)\end{array}$ & $\begin{array}{l}3 \% \\
(15)\end{array}$ & $\begin{array}{l}8 \% \\
(40)\end{array}$ & $\begin{array}{l}7.6 \% \\
(38)\end{array}$ & $31.4 \%$ & $3 \%$ & $15.6 \%$ \\
\hline $\begin{array}{l}\text { Physical make-up } \\
(26-30)\end{array}$ & $\begin{array}{l}3.2 \% \\
(16)\end{array}$ & $\begin{array}{l}7.8 \% \\
(39)\end{array}$ & $\begin{array}{c}1.8 \% \\
(9)\end{array}$ & $\begin{array}{c}14.4 \% \\
(72)\end{array}$ & $\begin{array}{l}22.8 \% \\
(114)\end{array}$ & $11 \%$ & $1.8 \%$ & $37.2 \%$ \\
\hline $\begin{array}{l}\text { Pronunciation } \\
\text { practice(31-34) }\end{array}$ & $\begin{array}{l}2 \% \\
(8)\end{array}$ & $\begin{array}{c}6.25 \% \\
(25)\end{array}$ & $\begin{array}{c}1.75 \% \\
(7)\end{array}$ & $\begin{array}{c}19.5 \% \\
(78)\end{array}$ & $\begin{array}{c}20.5 \% \\
(82)\end{array}$ & $8.25 \%$ & $\begin{array}{c}1.75 \\
\%\end{array}$ & $40 \%$ \\
\hline $\begin{array}{c}\text { Speaking section } \\
(35-39)\end{array}$ & $\begin{array}{l}1 \% \\
(5)\end{array}$ & $\begin{array}{l}2.4 \% \\
(12)\end{array}$ & $\begin{array}{c}1.4 \% \\
(7)\end{array}$ & $\begin{array}{c}17.2 \% \\
(86)\end{array}$ & $\begin{array}{l}28 \% \\
(140)\end{array}$ & $3.4 \%$ & $1.4 \%$ & $45.2 \%$ \\
\hline $\begin{array}{c}\text { Writing section } \\
(40-43)\end{array}$ & $\begin{array}{c}2.25 \% \\
(9)\end{array}$ & $\begin{array}{l}3.5 \% \\
(14)\end{array}$ & $\begin{array}{c}1.75 \% \\
(7)\end{array}$ & $\begin{array}{c}15.75 \% \\
(63)\end{array}$ & $\begin{array}{c}26.75 \% \\
(107)\end{array}$ & $5.75 \%$ & $\begin{array}{c}1.75 \\
\%\end{array}$ & $42.5 \%$ \\
\hline
\end{tabular}

Abbreviations: HE stands for Highly Effective, SE for Somewhat Effective, SI for Somewhat Ineffective, HI for Highly Ineffective, NK for 'I do not know', E for Effective, and I for Ineffective.

As Table 4 shows, the percentages of the responses rating actual activities, Language functions section, Reading section, Physical make-up, Pronunciation practice, Speaking section, and Writing section to be ineffective are significantly higher than the percentages of those that rated to be effective. However, the percentages of the responses rating grammatical points and Vocabulary items sections to be effective are significantly higher than the percentages of those that rated to be ineffective.

\subsection{Descriptive statistics for Items related to Different Sections of the Book Two(Teachers' Perceptions)}

The results of the items related to different sections of the second-year high school English textbook in the questionnaire from the teachers' perspective are demonstrated in Table 5.

Table 5. Presents the Percentages for Items related to Different Sections of the Book Two

\begin{tabular}{ccccccccc}
\hline & \multicolumn{3}{c}{ Teachers' Perceptions } & & \multicolumn{2}{c}{$\begin{array}{c}\text { Merging of the percentages } \\
\text { of the selected options }\end{array}$} \\
\cline { 2 - 9 } & HE & SE & NK & SI & HI & E & NK & I \\
\hline Actual activities & $3.4 \%$ & $7 \%$ & $5.4 \%$ & $14.6 \%$ & $19.5 \%$ & $10.4 \%$ & $5.4 \%$ & $34.1 \%$ \\
$(1-5)$ & $(17)$ & $(35)$ & $(27)$ & $(73)$ & $(98)$ & & & \\
\hline Language function & $2.2 \%$ & $8.8 \%$ & $5.8 \%$ & $12.6 \%$ & $20.6 \%$ & $11 \%$ & $5.8 \%$ & $33.2 \%$ \\
$(6-10)$ & $(11)$ & $(44)$ & $(29)$ & $(63)$ & $(103)$ & & & \\
\hline Reading section & $7.6 \%$ & $10.2 \%$ & $3.2 \%$ & $13.4 \%$ & $15.6 \%$ & $17.8 \%$ & $3.2 \%$ & $29 \%$ \\
$(11-15)$ & $(38)$ & $(51)$ & $(16)$ & $(67)$ & $(78)$ & & & \\
\hline
\end{tabular}




\begin{tabular}{|c|c|c|c|c|c|c|c|c|}
\hline ALLS 5(4):1-16, 2014 & & & & & & & & \\
\hline $\begin{array}{c}\text { Grammatical points } \\
(16-20)\end{array}$ & $\begin{array}{l}13 \% \\
(65) \\
\end{array}$ & $\begin{array}{l}15 \% \\
(75)\end{array}$ & $\begin{array}{l}3.6 \% \\
(18)\end{array}$ & $\begin{array}{c}8.8 \% \\
(44)\end{array}$ & $\begin{array}{c}9.6 \% \\
(48) \\
\end{array}$ & $28 \%$ & $3.6 \%$ & $18.4 \%$ \\
\hline $\begin{array}{c}\text { Vocabulary items } \\
(21-25)\end{array}$ & $\begin{array}{c}13.2 \% \\
(66)\end{array}$ & $\begin{array}{c}16.6 \% \\
(83)\end{array}$ & $\begin{array}{l}3.8 \% \\
(19)\end{array}$ & $\begin{array}{l}8.6 \% \\
(43)\end{array}$ & $\begin{array}{l}7.8 \% \\
(39)\end{array}$ & $29.8 \%$ & $3.8 \%$ & $16.4 \%$ \\
\hline $\begin{array}{c}\text { Physical make-up } \\
(26-30)\end{array}$ & $\begin{array}{l}2 \% \\
(10) \\
\end{array}$ & $\begin{array}{l}5.6 \% \\
(28) \\
\end{array}$ & $\begin{array}{c}2.6 \% \\
(13) \\
\end{array}$ & $\begin{array}{c}12.8 \% \\
(64) \\
\end{array}$ & $\begin{array}{l}27 \% \\
(135) \\
\end{array}$ & $7.6 \%$ & $2.6 \%$ & $39.8 \%$ \\
\hline $\begin{array}{l}\text { Pronunciation } \\
\text { practice(31-34) }\end{array}$ & $\begin{array}{l}2.25 \% \\
(9)\end{array}$ & $\begin{array}{c}6.25 \% \\
(25)\end{array}$ & $\begin{array}{l}5 \% \\
(20)\end{array}$ & $\begin{array}{l}14 \% \\
(56)\end{array}$ & $\begin{array}{c}22.5 \% \\
(90)\end{array}$ & $8.5 \%$ & $5 \%$ & $36.5 \%$ \\
\hline $\begin{array}{c}\text { Speaking section } \\
(35-39)\end{array}$ & $\begin{array}{c}1.6 \% \\
(8)\end{array}$ & $\begin{array}{c}8.4 \% \\
(42) \\
\end{array}$ & $\begin{array}{l}4 \% \\
(20) \\
\end{array}$ & $\begin{array}{l}15 \% \\
(75) \\
\end{array}$ & $\begin{array}{c}21 \% \\
(105) \\
\end{array}$ & $10 \%$ & $4 \%$ & $36 \%$ \\
\hline $\begin{array}{c}\text { Writing section } \\
(40-43)\end{array}$ & $\begin{array}{l}2 \% \\
(8)\end{array}$ & $\begin{array}{c}7.25 \% \\
(29)\end{array}$ & $\begin{array}{l}3 \% \\
(12)\end{array}$ & $\begin{array}{c}15.75 \% \\
(63)\end{array}$ & $\begin{array}{l}22 \% \\
(88)\end{array}$ & $9.25 \%$ & $3 \%$ & $37.75 \%$ \\
\hline
\end{tabular}

Abbreviations: HE stands for Highly Effective, SE for Somewhat Effective, SI for Somewhat Ineffective, HI for Highly Ineffective, NK for 'I do not know', E for Effective, and I for Ineffective.

As Table 5 shows, the teachers' responses have a tendency towards the ineffective end of the continuum in terms of Actual activities, Language functions section, Reading section, Physical make-up, Pronunciation practice, Speaking section, and Writing section. However, their responses only have a tendency towards the effective end of the continuum in terms of grammatical points and Vocabulary items sections.

\subsection{Descriptive statistics for Items related to Different Sections of the Book Three (Teachers' Perception)}

The results of the items related to different sections of the third-year high school English textbook in the questionnaire from the teachers' perspective are demonstrated in Table 6.

Table 6. Presents the Percentages for Items related to Different Sections of the Book Three

\begin{tabular}{|c|c|c|c|c|c|c|c|c|}
\hline & \multicolumn{5}{|c|}{ Teachers' Perceptions } & \multicolumn{3}{|c|}{$\begin{array}{l}\text { Merging of the percentages } \\
\text { of the selected options }\end{array}$} \\
\hline & $\mathrm{HE}$ & $\mathrm{SE}$ & NK & SI & HI & $E$ & NK & I \\
\hline \multirow{2}{*}{$\begin{array}{l}\text { Actual activities } \\
(1-5)\end{array}$} & $1 \%$ & $4.4 \%$ & $3.2 \%$ & $16.2 \%$ & $25.2 \%$ & $5.4 \%$ & $3.2 \%$ & $41.4 \%$ \\
\hline & (5) & (22) & $(16)$ & $(81)$ & $(126)$ & & & \\
\hline \multirow{2}{*}{$\begin{array}{l}\text { Language function } \\
\qquad(6-10)\end{array}$} & $2 \%$ & $5.4 \%$ & $3 \%$ & $12.8 \%$ & $26.8 \%$ & $7.4 \%$ & $3 \%$ & $39.6 \%$ \\
\hline & (10) & $(27)$ & (15) & $(64)$ & (134) & & & \\
\hline \multirow{2}{*}{$\begin{array}{c}\text { Reading section } \\
(11-15)\end{array}$} & $6.4 \%$ & $8.8 \%$ & $3.8 \%$ & $15 \%$ & $16 \%$ & $15.2 \%$ & $3.8 \%$ & $31 \%$ \\
\hline & $(32)$ & $(44)$ & (19) & (75) & (80) & & & \\
\hline \multirow{2}{*}{$\begin{array}{l}\text { Grammatical points } \\
(16-20)\end{array}$} & $11.4 \%$ & $15 \%$ & $3.4 \%$ & $9.2 \%$ & $11 \%$ & $26.4 \%$ & $3.4 \%$ & $20.2 \%$ \\
\hline & $(57)$ & $(75)$ & (17) & $(46)$ & (55) & & & \\
\hline \multirow{2}{*}{$\begin{array}{c}\text { Vocabulary items } \\
(21-25)\end{array}$} & $13.8 \%$ & $19 \%$ & $5 \%$ & $4.6 \%$ & $7.6 \%$ & $32.8 \%$ & $5 \%$ & $9.2 \%$ \\
\hline & $(69)$ & (95) & $(25)$ & $(23)$ & (38) & & & \\
\hline \multirow{2}{*}{$\begin{array}{l}\text { Physical make-up } \\
(26-30)\end{array}$} & $1.8 \%$ & $4.2 \%$ & $2.6 \%$ & $12.8 \%$ & $28.6 \%$ & $6 \%$ & $2.6 \%$ & $41.4 \%$ \\
\hline & $(9)$ & $(21)$ & (13) & $(64)$ & $(143)$ & & & \\
\hline \multirow{2}{*}{$\begin{array}{c}\text { Pronunciation } \\
\text { practice(31-34) }\end{array}$} & $1.75 \%$ & $5 \%$ & $3.25 \%$ & $19.5 \%$ & $20.5 \%$ & $6.75 \%$ & $3.25 \%$ & $40 \%$ \\
\hline & (7) & (20) & $(13)$ & $(78)$ & $(82)$ & & & \\
\hline \multirow{2}{*}{$\begin{array}{c}\text { Speaking section } \\
(35-39)\end{array}$} & $1 \%$ & $3.2 \%$ & $2.4 \%$ & $13 \%$ & $30.4 \%$ & $4.2 \%$ & $2.4 \%$ & $43.4 \%$ \\
\hline & (5) & (16) & (12) & (65) & (152) & & & \\
\hline \multirow{2}{*}{$\begin{array}{c}\text { Writing section } \\
(40-43)\end{array}$} & $2.75 \%$ & $4 \%$ & $2.75 \%$ & $13 \%$ & $27.5 \%$ & $6.75 \%$ & $2.75 \%$ & $40.5 \%$ \\
\hline & (11) & (16) & $(11)$ & (52) & (110) & & & \\
\hline
\end{tabular}

Abbreviations: HE stands for Highly Effective, SE for Somewhat Effective, SI for Somewhat Ineffective, HI for Highly Ineffective, NK for 'I do not know', E for Effective, and I for Ineffective.

As Table 6 shows, the percentages of the responses rating actual activities, Language functions section, Reading section, Physical make-up, Pronunciation practice, Speaking section, and Writing section to be ineffective are significantly higher than the percentages of those that rated to be effective. However, the percentages of the responses rating grammatical points and Vocabulary items sections to be effective are significantly higher than the percentages of those that rated to be ineffective. 
As Tables 1, 2, 3, 4, 5, and 6 show actual activities, language functions, reading section, physical appearance, pronunciation points, speaking section, and writing section of the three high school English language textbooks which the learners rated them as being ineffective and vocabulary items, and grammatical points as effective were rated as the same by the teachers.

4.7 The obtained mean and Std. Deviation for learners' and teachers' perceptions about different sections of Book 1

Table 7. The obtained mean and Std. Deviation for learners' and teachers' perceptions about different sections of (Book 1)

Group Statistics

\begin{tabular}{llllll}
\hline \multirow{2}{*}{ Group } & & & & Std. Error \\
& & $\mathrm{N}$ & Mean & Std. Deviation & Mean \\
\hline Actual activity & Learners & 100 & 20.5300 & 3.17011 & .31701 \\
Language functions & Teachers & 50 & 20.1000 & 2.76457 & .39097 \\
& Learners & 100 & 20.3300 & 3.08484 & .30848 \\
Reading section & Teachers & 50 & 20.7800 & 2.71271 & .38363 \\
& Learners & 100 & 16.9300 & 4.52659 & .45266 \\
Grammatical points & Teachers & 50 & 18.3200 & 3.24157 & .45843 \\
& Learners & 100 & 14.1800 & 3.77225 & .37723 \\
Vocabulary items & Teachers & 50 & 12.3800 & 3.27570 & .46325 \\
& Learners & 100 & 12.0300 & 4.16686 & .41669 \\
Physical appearance & Teachers & 50 & 12.8600 & 3.64221 & .51509 \\
& Learners & 100 & 19.7100 & 4.19306 & .41931 \\
Pronunciation points & Teachers & 50 & 19.5800 & 4.01573 & .56791 \\
& Learners & 100 & 15.2200 & 3.73512 & .37351 \\
Speaking section & Teachers & 50 & 16.0200 & 3.25445 & .46025 \\
\multirow{3}{*}{ Writing section } & Learners & 100 & 21.0900 & 4.69277 & .46928 \\
& Teachers & 50 & 21.8800 & 2.45482 & .34716 \\
Total & Learners & 100 & 16.3300 & 3.25687 & .32569 \\
& Teachers & 50 & 16.9000 & 2.54951 & .36056 \\
\hline & Learners & 100 & 156.3500 & 18.60074 & 1.86007 \\
& Teachers & 50 & 158.8200 & 15.99195 & 2.26160 \\
\hline
\end{tabular}

Table 7 demonstrates that the mean score difference is not meaningful in terms of actual activities, language functions section, vocabulary items, pronunciation points, physical appearance, speaking section, and writing section, the mean score difference is not meaningful when the whole book is taken into consideration as well. However, as can be seen, the mean score difference is meaningful in terms of reading section, and grammatical points.

4.8 The obtained mean and Std. Deviation for learners' and teachers' perceptions about different sections of Book2 Table 8. The obtained mean and Std. Deviation for learners' and teachers' perceptions about different sections of (Book

2)

Group Statistics

\begin{tabular}{llllll}
\hline \multirow{2}{*}{ Actual activity } & Group & $\mathrm{N}$ & Mean & Std. Deviation & Std. Error Mean \\
\hline \multirow{4}{*}{ Language function } & Learners & 100 & 19.2300 & 3.39297 & .33930 \\
& Teachers & 50 & 19.0000 & 2.93466 & .41502 \\
Reading section & Learners & 100 & 18.1200 & 3.27611 & .32761 \\
& Teachers & 50 & 19.0600 & 3.12599 & .44208 \\
Grammatical points & Learners & 100 & 17.2500 & 3.63867 & .36387 \\
& Teachers & 50 & 16.9200 & 3.68583 & .52125 \\
Vocabulary items & Learners & 100 & 13.1000 & 3.14466 & .31447 \\
& Teachers & 50 & 13.7000 & 3.44786 & .48760 \\
Physical appearance & Learners & 100 & 11.7700 & 3.91283 & .39128 \\
& Teachers & 50 & 13.1200 & 3.89474 & .55080 \\
Pronunciation points & Learners & 100 & 17.6300 & 4.07668 & .40767 \\
\multirow{5}{*}{ Speaking section } & Teachers & 50 & 20.7200 & 3.16254 & .44725 \\
& Learners & 100 & 14.5400 & 3.48857 & .34886 \\
Writing section & Teachers & 50 & 15.8600 & 3.28888 & .46512 \\
\multirow{2}{*}{ Total } & Learners & 100 & 19.7200 & 4.89502 & .48950 \\
& Teachers & 50 & 19.5400 & 3.13121 & .44282 \\
& Learners & 100 & 14.3300 & 3.21001 & .32100 \\
\hline
\end{tabular}


Table 8 demonstrates that the mean score difference is not meaningful in terms of actual activities, language functions section, grammatical points, reading section, and speaking section. However, as can be seen, the mean score difference is meaningful in terms of pronunciation points, vocabulary items, physical make-up, and writing section. The mean score difference is meaningful when the whole book is taken into consideration as well.

\subsection{The obtained mean and Std. Deviation for learners' and teachers' perceptions about different sections of Book 3}

Table 9. The obtained mean and Std. Deviation for learners' and teachers' perceptions about different sections of (Book 3)

\begin{tabular}{llllll} 
Group Statistics & Group & $\mathrm{N}$ & Mean & Std. Deviation & Std. Error Mean \\
\hline \multirow{2}{*}{ Actual activity } & Learners & 100 & 18.4600 & 2.77951 & .27795 \\
& Teachers & 50 & 21.0200 & 2.55942 & .36196 \\
Language functions & Learners & 100 & 19.2300 & 3.22821 & .32282 \\
& Teachers & 50 & 20.7000 & 2.49285 & .35254 \\
Reading section & Learners & 100 & 17.1900 & 3.26504 & .32650 \\
& Teachers & 50 & 17.5400 & 3.17008 & .44832 \\
Grammatical points & Learners & 100 & 13.6100 & 3.31478 & .33148 \\
& Teachers & 50 & 14.3400 & 3.31730 & .46914 \\
Vocabulary items & Learners & 100 & 13.1200 & 3.77199 & .37720 \\
& Teachers & 50 & 12.3200 & 4.02259 & .56888 \\
Physical appearance & Learners & 100 & 18.0200 & 3.73350 & .37335 \\
\multirow{3}{*}{ Pronunciation points } & Teachers & 50 & 21.2200 & 2.69004 & .38043 \\
\multirow{2}{*}{ Speaking section } & Learners & 100 & 14.0500 & 3.72915 & .37292 \\
& Teachers & 50 & 16.1600 & 2.74315 & .38794 \\
Writing section & Learners & 100 & 18.9100 & 4.47461 & .44746 \\
& Teachers & 50 & 21.8600 & 2.57943 & .36479 \\
Total & Learners & 100 & 14.6200 & 2.75893 & .27589 \\
& Teachers & 50 & 16.6800 & 2.58283 & .36527 \\
& Learners & 100 & 147.2100 & 12.71466 & 1.27147 \\
& Teachers & 50 & 161.8400 & 13.68354 & 1.93514 \\
\hline
\end{tabular}

Table 9 demonstrates that the mean score difference is not meaningful in terms of grammatical points, vocabulary items, and reading section. However, as can be seen, the mean score difference is meaningful in terms of actual activities, language functions section, pronunciation points, physical make-up, speaking section, and writing section. The mean score difference is meaningful when the whole book is taken into consideration as well.

\subsection{Independent-sample t-test results for Learners' and Teachers' Perceptions about Different Sections of Book1}

Table 10: Independent-sample t-test results for learners' and teachers' perceptions about actual activities, language functions, reading section, grammatical points, and vocabulary items of Book1

\begin{tabular}{|c|c|c|c|c|c|c|c|c|c|c|}
\hline & & \multicolumn{4}{|c|}{$\begin{array}{l}\text { Levene's Test } \\
\text { for Equality of } \\
\text { Variances }\end{array}$} & \multicolumn{3}{|c|}{ t-test for Equality of Means } & \multirow{2}{*}{\multicolumn{2}{|c|}{$\begin{array}{l}\text { 95\% Confidence Interval of } \\
\text { the Difference }\end{array}$}} \\
\hline & & \multirow[b]{2}{*}{$\mathrm{F}$} & \multirow[b]{2}{*}{ Sig. } & \multirow[b]{2}{*}{$\mathrm{T}$} & \multirow[b]{2}{*}{ Df } & \multirow{2}{*}{$\begin{array}{l}\text { Sig. }(2- \\
\text { tailed) }\end{array}$} & \multirow{2}{*}{$\begin{array}{l}\text { Mean } \\
\text { Difference }\end{array}$} & \multirow{2}{*}{$\begin{array}{l}\text { Std. Error } \\
\text { Difference }\end{array}$} & & \\
\hline & & & & & & & & & Lower & Upper \\
\hline \multirow[t]{2}{*}{ Actual activity } & $\begin{array}{l}\text { Equal variances } \\
\text { assumed }\end{array}$ & 1.700 & .194 & .816 & 148 & .416 & .43000 & .52686 & -.61114 & 1.47114 \\
\hline & $\begin{array}{l}\text { Equal variances } \\
\text { not assumed }\end{array}$ & & & .854 & 110.887 & .395 & .43000 & .50334 & -.56742 & 1.42742 \\
\hline \multirow[t]{2}{*}{$\begin{array}{l}\text { Language } \\
\text { functions }\end{array}$} & $\begin{array}{l}\text { Equal variances } \\
\text { assumed }\end{array}$ & 2.795 & .097 & -.876 & 148 & .383 & -.45000 & .51387 & -1.46546 & .56546 \\
\hline & $\begin{array}{l}\text { Equal variances } \\
\text { not assumed }\end{array}$ & & & -.914 & 110.074 & .363 & -.45000 & .49228 & -1.42557 & .52557 \\
\hline \multirow[t]{2}{*}{$\begin{array}{l}\text { Reading } \\
\text { section }\end{array}$} & $\begin{array}{l}\text { Equal variances } \\
\text { assumed }\end{array}$ & 6.858 & .010 & -1.936 & 148 & .055 & -1.39000 & .71802 & -2.80889 & .02889 \\
\hline & $\begin{array}{l}\text { Equal variances } \\
\text { not assumed }\end{array}$ & & & -2.158 & 129.975 & .033 & -1.39000 & .64425 & -2.66457 & -.11543 \\
\hline \multirow[t]{2}{*}{$\begin{array}{l}\text { Grammatical } \\
\text { points }\end{array}$} & $\begin{array}{l}\text { Equal variances } \\
\text { assumed }\end{array}$ & .474 & .492 & 2.874 & 148 & .005 & 1.80000 & .62621 & .56254 & 3.03746 \\
\hline & $\begin{array}{l}\text { Equal variances } \\
\text { not assumed }\end{array}$ & & & 3.013 & 111.304 & .003 & 1.80000 & .59741 & .61622 & 2.98378 \\
\hline \multirow[t]{2}{*}{$\begin{array}{l}\text { Vocabulary } \\
\text { items }\end{array}$} & $\begin{array}{l}\text { Equal variances } \\
\text { assumed }\end{array}$ & .863 & .354 & -1.198 & 148 & .233 & -.83000 & 69296 & -2.19937 & .53937 \\
\hline & $\begin{array}{l}\text { Equal variances } \\
\text { not assumed }\end{array}$ & & & -1.253 & 110.661 & .213 & -.83000 & .66253 & -2.14289 & .48289 \\
\hline
\end{tabular}


Table 11. Independent-sample t-test results for learners' and teachers' perceptions about physical appearance, pronunciation points, speaking section, writing section of Book1

Independent Samples Test

\begin{tabular}{|c|c|c|c|c|c|c|c|c|c|c|}
\hline & & \multicolumn{4}{|c|}{$\begin{array}{l}\text { Levene's Test } \\
\text { for Equality of } \\
\text { Variances }\end{array}$} & \multicolumn{3}{|c|}{ t-test for Equality of Means } & & \\
\hline & & \multirow[b]{2}{*}{$\mathrm{F}$} & \multirow[b]{2}{*}{ Sig. } & \multirow[b]{2}{*}{$\mathrm{T}$} & \multirow[b]{2}{*}{ Df } & \multirow{2}{*}{$\begin{array}{l}\text { Sig. }(2- \\
\text { tailed) }\end{array}$} & \multirow{2}{*}{$\begin{array}{l}\text { Mean } \\
\text { Difference }\end{array}$} & \multirow{2}{*}{$\begin{array}{l}\text { Std. Error } \\
\text { Differenc } \\
\text { e }\end{array}$} & \multicolumn{2}{|c|}{$\begin{array}{l}95 \% \text { Confidence Interval of } \\
\text { the Difference }\end{array}$} \\
\hline & & & & & & & & & Lower & Upper \\
\hline \multirow[t]{2}{*}{$\begin{array}{l}\text { Physical } \\
\text { appearance }\end{array}$} & $\begin{array}{l}\text { Equal variances } \\
\text { assumed }\end{array}$ & .178 & .674 & .182 & 148 & .856 & .13000 & .71624 & -1.28537 & 1.54537 \\
\hline & $\begin{array}{l}\text { Equal variances } \\
\text { not assumed }\end{array}$ & & & .184 & 101.984 & .854 & .13000 & .70593 & -1.27021 & 1.53021 \\
\hline \multirow[t]{2}{*}{$\begin{array}{l}\text { Pronunciation } \\
\text { points }\end{array}$} & $\begin{array}{l}\text { Equal variances } \\
\text { assumed }\end{array}$ & .115 & .735 & -1.289 & 148 & .199 & -.80000 & .62062 & -2.02641 & .42641 \\
\hline & $\begin{array}{l}\text { Equal variances } \\
\text { not assumed }\end{array}$ & & & -1.350 & 110.973 & .180 & -.80000 & .59274 & -1.97456 & .37456 \\
\hline \multirow[t]{2}{*}{$\begin{array}{l}\text { Speaking } \\
\text { section }\end{array}$} & $\begin{array}{l}\text { Equal variances } \\
\text { assumed }\end{array}$ & 8.649 & .004 & -1.115 & 148 & .267 & -.79000 & .70837 & -2.18982 & .60982 \\
\hline & $\begin{array}{l}\text { Equal variances } \\
\text { not assumed }\end{array}$ & & & -1.353 & 147.659 & .178 & -.79000 & .58373 & -1.94355 & .36355 \\
\hline \multirow[t]{2}{*}{$\begin{array}{l}\text { Writing } \\
\text { section }\end{array}$} & $\begin{array}{l}\text { Equal variances } \\
\text { assumed }\end{array}$ & .480 & .490 & -1.082 & 148 & .281 & -.57000 & .52671 & -1.61084 & .47084 \\
\hline & $\begin{array}{l}\text { Equal variances } \\
\text { not assumed }\end{array}$ & & & -1.173 & 121.536 & .243 & -.57000 & .48587 & -1.53187 & .39187 \\
\hline
\end{tabular}

The results of Table 10 and Table 11 indicate that the level of meaningfulness in actual activities, language functions section, vocabulary items, physical appearance, pronunciation points, speaking section, and writing section is more than 0.05; therefore, the mean score difference is not meaningful. As can be seen, no significant difference exists between learners' perceptions and teachers' perceptions in terms of actual activities, language functions section, vocabulary items, physical appearance, pronunciation points, speaking section, and writing section of the first-year high school English textbook. The results of the Tables also indicate that the level of meaningfulness only in reading section, and grammatical points is less than 0.05 . It could be concluded that there is a meaningful difference between learners' perceptions and teachers' perceptions in terms of reading section, and grammatical points of the first-year high school English textbook.

\subsection{Independent-sample t-test results for Learners' and Teachers' Perceptions about Different Sections of Book 2}

Table 12. Independent Sample t-test results for Learners' and Teachers' Perceptions about Actual Activities, Language Functions, Reading Section, Grammatical Points, and Vocabulary Items of Book2

\begin{tabular}{|c|c|c|c|c|c|c|c|c|c|c|}
\hline & & $\begin{array}{l}\text { Leven } \\
\text { for } \mathrm{Eq} \\
\text { of } \mathrm{Var}\end{array}$ & $\begin{array}{l}\text { 's Test } \\
\text { dality } \\
\text { ances }\end{array}$ & \multicolumn{7}{|c|}{ t-test for Equality of Means } \\
\hline & & \multirow[b]{2}{*}{$\mathrm{F}$} & \multirow[b]{2}{*}{ Sig. } & \multirow[b]{2}{*}{$\mathrm{T}$} & \multirow[b]{2}{*}{ Df } & \multirow{2}{*}{$\begin{array}{l}\text { Sig. (2- } \\
\text { tailed) }\end{array}$} & \multirow{2}{*}{$\begin{array}{l}\text { Mean } \\
\text { Difference }\end{array}$} & \multirow{2}{*}{$\begin{array}{l}\text { Std. Error } \\
\text { Difference }\end{array}$} & \multicolumn{2}{|c|}{$\begin{array}{l}95 \% \text { Confidence } \\
\text { Interval of the } \\
\text { Difference }\end{array}$} \\
\hline & & & & & & & & & Lower & Upper \\
\hline \multirow[t]{2}{*}{$\begin{array}{l}\text { Actual } \\
\text { activity }\end{array}$} & $\begin{array}{l}\text { Equal variances } \\
\text { assumed }\end{array}$ & 4.408 & .037 & .409 & 148 & .683 & .23000 & .56264 & -.88184 & 1.34184 \\
\hline & $\begin{array}{l}\text { Equal variances } \\
\text { not assumed }\end{array}$ & & & .429 & $\begin{array}{l}111 . \\
693\end{array}$ & .669 & .23000 & .53607 & -.83218 & 1.29218 \\
\hline \multirow[t]{2}{*}{$\begin{array}{l}\text { Language } \\
\text { function }\end{array}$} & $\begin{array}{l}\text { Equal variances } \\
\text { assumed }\end{array}$ & 1.238 & .268 & -1.682 & 148 & .095 & -.94000 & .55897 & -2.04458 & .16458 \\
\hline & $\begin{array}{l}\text { Equal variances } \\
\text { not assumed }\end{array}$ & & & -1.708 & $\begin{array}{l}102 . \\
323\end{array}$ & .091 & -.94000 & .55024 & -2.03136 & .15136 \\
\hline \multirow[t]{2}{*}{$\begin{array}{l}\text { Reading } \\
\text { section }\end{array}$} & $\begin{array}{l}\text { Equal variances } \\
\text { assumed }\end{array}$ & .111 & .739 & .521 & 148 & .603 & .33000 & .63295 & -.92079 & 1.58079 \\
\hline & $\begin{array}{l}\text { Equal variances } \\
\text { not assumed }\end{array}$ & & & .519 & $\begin{array}{l}96.9 \\
90\end{array}$ & .605 & .33000 & .63569 & -.93168 & 1.59168 \\
\hline \multirow[t]{2}{*}{$\begin{array}{l}\text { Grammatical } \\
\text { points }\end{array}$} & $\begin{array}{l}\text { Equal variances } \\
\text { assumed }\end{array}$ & 1.348 & .248 & -1.066 & 148 & .288 & -.60000 & .56260 & -1.71177 & .51177 \\
\hline & $\begin{array}{l}\text { Equal variances } \\
\text { not assumed }\end{array}$ & & & -1.034 & $\begin{array}{l}90.4 \\
90\end{array}$ & .304 & -.60000 & .58021 & -1.75260 & .55260 \\
\hline \multirow[t]{2}{*}{$\begin{array}{l}\text { Vocabulary } \\
\text { items }\end{array}$} & $\begin{array}{l}\text { Equal variances } \\
\text { assumed }\end{array}$ & .000 & .996 & -1.995 & 148 & .048 & -1.35000 & .67669 & -2.68721 & -.01279 \\
\hline & $\begin{array}{l}\text { Equal variances } \\
\text { not assumed }\end{array}$ & & & -1.998 & $\begin{array}{l}98.5 \\
17\end{array}$ & .048 & -1.35000 & .67563 & -2.69069 & -.00931 \\
\hline
\end{tabular}


Table 13. Independent Sample t-test results for Learners' and Teachers' Perceptions about Physical Appearance, Pronunciation Points, Speaking Section, Writing Section of Book2

Independent Samples Test

\begin{tabular}{|c|c|c|c|c|c|c|c|c|c|c|}
\hline & & \multicolumn{4}{|c|}{$\begin{array}{l}\text { Levene's Test } \\
\text { for Equality } \\
\text { of Variances }\end{array}$} & \multicolumn{5}{|c|}{ t-test for Equality of Means } \\
\hline & & \multirow[b]{2}{*}{$\mathrm{F}$} & \multirow[b]{2}{*}{ Sig. } & \multirow[b]{2}{*}{$\mathrm{T}$} & \multirow[b]{2}{*}{ Df } & \multirow{2}{*}{$\begin{array}{l}\text { Sig. } \\
(2- \\
\text { tailed } \\
)\end{array}$} & \multirow{2}{*}{$\begin{array}{l}\text { Mean } \\
\text { Differen } \\
\text { ce }\end{array}$} & \multirow{2}{*}{$\begin{array}{l}\text { Std. } \\
\text { Error } \\
\text { Differe } \\
\text { nce } \\
\end{array}$} & \multicolumn{2}{|c|}{$\begin{array}{l}95 \% \text { Confidence } \\
\text { Interval of the } \\
\text { Difference }\end{array}$} \\
\hline & & & & & & & & & Lower & Upper \\
\hline \multirow[t]{2}{*}{$\begin{array}{l}\text { Physical } \\
\text { appearance }\end{array}$} & $\begin{array}{l}\text { Equal } \\
\text { variances } \\
\text { assumed }\end{array}$ & 6.575 & .011 & -4.697 & 148 & .000 & $\begin{array}{l}- \\
3.09000\end{array}$ & .65791 & $\begin{array}{l}- \\
4.39012\end{array}$ & $\begin{array}{l}- \\
1.7898 \\
8\end{array}$ \\
\hline & $\begin{array}{l}\text { Equal } \\
\text { variances not } \\
\text { assumed }\end{array}$ & & & -5.106 & 122.420 & .000 & $\begin{array}{l}- \\
3.09000\end{array}$ & .60517 & $\begin{array}{l}- \\
4.28794\end{array}$ & $\begin{array}{l}- \\
1.8920 \\
6\end{array}$ \\
\hline \multirow[t]{2}{*}{$\begin{array}{l}\text { Pronunciatio } \\
\mathrm{n} \text { points }\end{array}$} & $\begin{array}{l}\text { Equal } \\
\text { variances } \\
\text { assumed }\end{array}$ & .000 & .987 & -2.226 & 148 & .028 & $\begin{array}{l}- \\
1.32000\end{array}$ & .59301 & $\begin{array}{l}- \\
2.49186\end{array}$ & $\begin{array}{l}- \\
.14814\end{array}$ \\
\hline & $\begin{array}{l}\text { Equal } \\
\text { variances not } \\
\text { assumed }\end{array}$ & & & -2.270 & 103.436 & .025 & $\begin{array}{l}- \\
1.32000\end{array}$ & .58141 & $\begin{array}{l}- \\
2.47303\end{array}$ & $\begin{array}{l}- \\
.16697\end{array}$ \\
\hline \multirow[t]{2}{*}{$\begin{array}{l}\text { Speaking } \\
\text { section }\end{array}$} & $\begin{array}{l}\text { Equal } \\
\text { variances } \\
\text { assumed }\end{array}$ & 8.298 & .005 & .237 & 148 & .813 & .18000 & .76041 & $\begin{array}{l}- \\
1.32267\end{array}$ & $\begin{array}{l}1.6826 \\
7\end{array}$ \\
\hline & $\begin{array}{l}\text { Equal } \\
\text { variances not } \\
\text { assumed }\end{array}$ & & & .273 & 139.109 & .785 & .18000 & .66008 & $\begin{array}{l}- \\
1.12508\end{array}$ & $\begin{array}{l}1.4850 \\
8\end{array}$ \\
\hline \multirow[t]{2}{*}{$\begin{array}{l}\text { Writing } \\
\text { section }\end{array}$} & $\begin{array}{l}\text { Equal } \\
\text { variances } \\
\text { assumed }\end{array}$ & .473 & .493 & -2.898 & 148 & .004 & $\begin{array}{l}- \\
1.55000\end{array}$ & .53488 & $\begin{array}{l}- \\
2.60698\end{array}$ & $\begin{array}{l}- \\
.49302\end{array}$ \\
\hline & $\begin{array}{l}\text { Equal } \\
\text { variances not } \\
\text { assumed } \\
\end{array}$ & & & -3.024 & 109.969 & .003 & $\begin{array}{l}- \\
1.55000\end{array}$ & .51259 & - 2.56583 & - \\
\hline
\end{tabular}

The results of the data analysis indicated that the level of meaningfulness in actual activities, language functions section, reading section, grammatical points, and speaking section of the second-year high school English textbook is more than 0.05 ; therefore, the mean score difference is not meaningful. Therefore, no significant difference exists between learners' perceptions and teachers' perceptions in terms of actual activities, language functions section, reading section, grammatical points, and speaking section of the second-year high school English textbook. The results of the data analysis also indicated that the level of meaningfulness in vocabulary items, physical appearance, pronunciation points, and writing section of the second-year high school English textbook is less than 0.05. Therefore, there is a meaningful difference between learners' perceptions and teachers' perceptions in terms of vocabulary items, physical appearance, pronunciation points and writing section of the second-year high school English textbook.

\subsection{Independent-sample t-test results for Learners' and Teachers' Perceptions about Different Sections of Book3}

Table 14: Independent Samples t-Test for Learners' and Teachers' Perceptions about Actual Activities, Language Functions, Reading Section, Grammatical Points, and Vocabulary Items of Book3

Independent Samples Test

\begin{tabular}{|c|c|c|c|c|c|c|c|c|c|c|}
\hline & & \multicolumn{4}{|c|}{$\begin{array}{l}\text { Levene's Test } \\
\text { for Equality of } \\
\text { Variances }\end{array}$} & \multicolumn{5}{|c|}{ t-test for Equality of Means } \\
\hline & & \multirow[b]{2}{*}{$\mathrm{F}$} & \multirow[b]{2}{*}{ Sig. } & \multirow[b]{2}{*}{$\mathrm{T}$} & \multirow[b]{2}{*}{ Df } & \multirow{2}{*}{$\begin{array}{l}\text { Sig. (2- } \\
\text { tailed) }\end{array}$} & \multirow{2}{*}{$\begin{array}{l}\text { Mean } \\
\text { Differen } \\
\text { ce }\end{array}$} & \multirow{2}{*}{$\begin{array}{l}\text { Std. } \\
\text { Error } \\
\text { Differe } \\
\text { nce } \\
\end{array}$} & \multicolumn{2}{|c|}{$\begin{array}{l}95 \% \text { Confidence } \\
\text { Interval of the } \\
\text { Difference }\end{array}$} \\
\hline & & & & & & & & & Lower & Upper \\
\hline \multirow[t]{2}{*}{$\begin{array}{l}\text { Actual } \\
\text { activity }\end{array}$} & $\begin{array}{l}\text { Equal } \\
\text { variances } \\
\text { assumed }\end{array}$ & 1.147 & .286 & -5.457 & 148 & .000 & $\begin{array}{l}- \\
2.56000\end{array}$ & .46915 & $\begin{array}{l}- \\
3.48709\end{array}$ & -1.63291 \\
\hline & $\begin{array}{l}\text { Equal } \\
\text { variances not } \\
\text { assumed }\end{array}$ & & & -5.610 & $\begin{array}{l}105.64 \\
6\end{array}$ & .000 & $\begin{array}{l}- \\
2.56000\end{array}$ & .45636 & $\begin{array}{l}- \\
3.46482\end{array}$ & -1.65518 \\
\hline
\end{tabular}




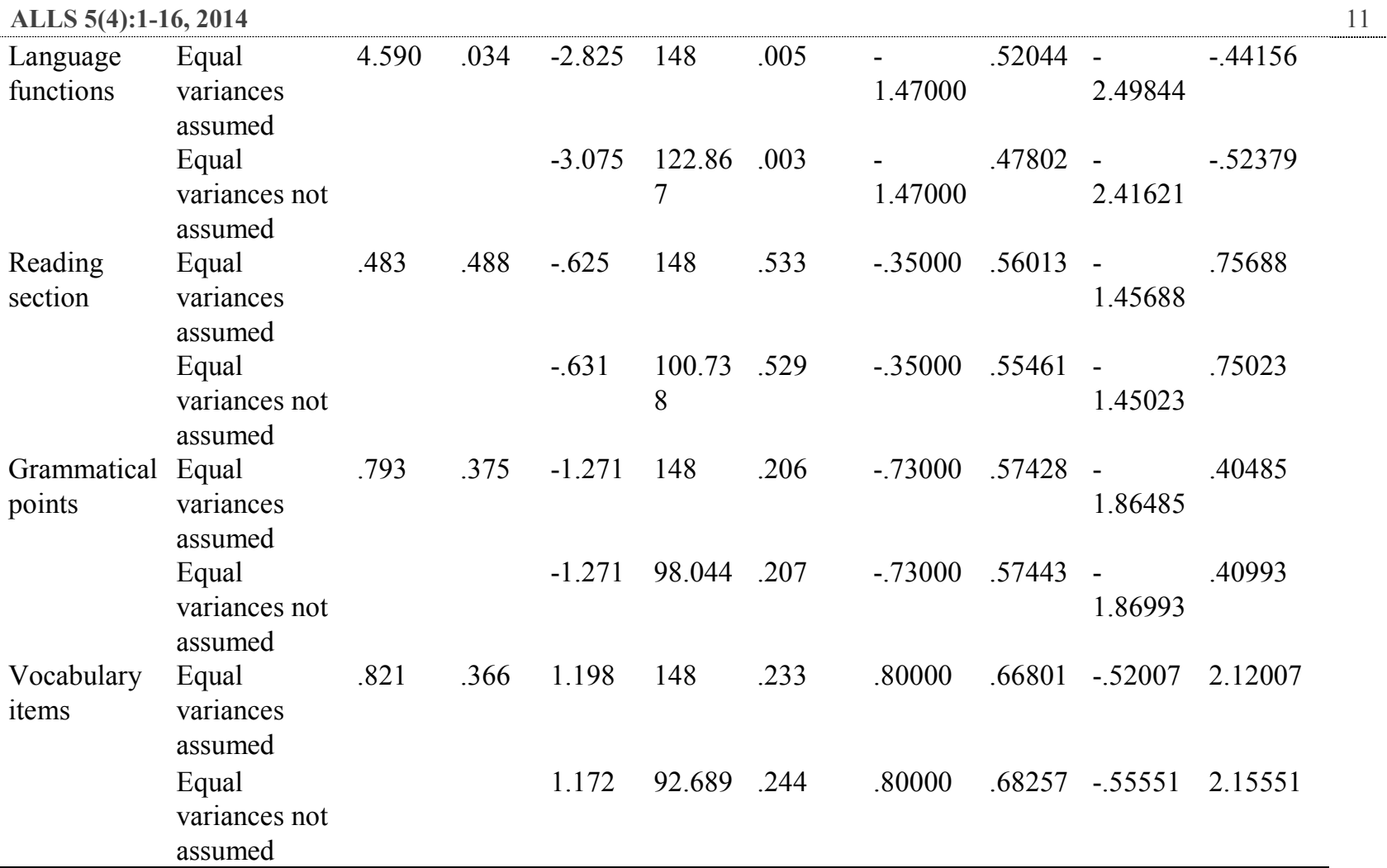

Table 15. Independent Samples t-Test for Learners' and Teachers' Perceptions about Physical Appearance, Pronunciation Points, Speaking Section, Writing Section of Book3

Independent Samples Test

\begin{tabular}{|c|c|c|c|c|c|c|c|c|c|c|}
\hline & & \multicolumn{4}{|c|}{$\begin{array}{l}\text { Levene's } \\
\text { Test for } \\
\text { Equality of } \\
\text { Variances } \\
\end{array}$} & \multicolumn{5}{|c|}{ t-test for Equality of Means } \\
\hline & & \multirow[b]{2}{*}{$\mathrm{F}$} & \multirow[b]{2}{*}{ Sig. } & \multirow[b]{2}{*}{$\mathrm{T}$} & \multirow[b]{2}{*}{ Df } & \multirow{2}{*}{$\begin{array}{l}\text { Sig. } \\
(2- \\
\text { tailed } \\
)\end{array}$} & \multirow{2}{*}{$\begin{array}{l}\text { Mean } \\
\text { Differenc } \\
\text { e }\end{array}$} & \multirow{2}{*}{$\begin{array}{l}\text { Std. } \\
\text { Error } \\
\text { Differe } \\
\text { nce }\end{array}$} & \multicolumn{2}{|c|}{$\begin{array}{l}95 \% \text { Confidence } \\
\text { Interval of the } \\
\text { Difference } \\
\end{array}$} \\
\hline & & & & & & & & & Lower & Upper \\
\hline $\begin{array}{l}\text { Physical } \\
\text { appearance }\end{array}$ & $\begin{array}{l}\text { Equal } \\
\text { variances } \\
\text { assumed }\end{array}$ & $\begin{array}{l}5.33 \\
7\end{array}$ & .022 & -5.397 & 148 & .000 & -3.20000 & .59296 & -4.37175 & $\begin{array}{l}- \\
2.02825\end{array}$ \\
\hline & $\begin{array}{l}\text { Equal } \\
\text { variances not } \\
\text { assumed }\end{array}$ & & & -6.003 & 129.420 & .000 & -3.20000 & .53303 & -4.25457 & $\begin{array}{l}- \\
2.14543\end{array}$ \\
\hline \multirow[t]{2}{*}{$\begin{array}{l}\text { Pronunciati } \\
\text { on points }\end{array}$} & $\begin{array}{l}\text { Equal } \\
\text { variances } \\
\text { assumed }\end{array}$ & $\begin{array}{l}7.20 \\
1\end{array}$ & .008 & -3.547 & 148 & .001 & -2.11000 & .59482 & -3.28544 & -.93456 \\
\hline & $\begin{array}{l}\text { Equal } \\
\text { variances not } \\
\text { assumed }\end{array}$ & & & -3.921 & 127.508 & .000 & -2.11000 & .53811 & -3.17478 & $\begin{array}{l}- \\
1.04522\end{array}$ \\
\hline \multirow[t]{2}{*}{$\begin{array}{l}\text { Speaking } \\
\text { section }\end{array}$} & $\begin{array}{l}\text { Equal } \\
\text { variances } \\
\text { assumed }\end{array}$ & $\begin{array}{l}16.3 \\
13\end{array}$ & .000 & -4.313 & 148 & .000 & -2.95000 & .68402 & -4.30170 & $\begin{array}{l}- \\
1.59830\end{array}$ \\
\hline & $\begin{array}{l}\text { Equal } \\
\text { variances not } \\
\text { assumed }\end{array}$ & & & -5.110 & 144.958 & .000 & -2.95000 & .57731 & -4.09104 & - 1.80896 \\
\hline \multirow[t]{2}{*}{$\begin{array}{l}\text { Writing } \\
\text { section }\end{array}$} & $\begin{array}{l}\text { Equal } \\
\text { variances } \\
\text { assumed }\end{array}$ & .667 & .416 & -4.402 & 148 & .000 & -2.06000 & .46798 & -2.98479 & $\begin{array}{l}- \\
1.13521\end{array}$ \\
\hline & $\begin{array}{l}\text { Equal } \\
\text { variances not } \\
\text { assumed } \\
\end{array}$ & & & -4.500 & 104.090 & .000 & -2.06000 & .45775 & -2.96773 & $\begin{array}{l}- \\
1.15227\end{array}$ \\
\hline
\end{tabular}

The results of the Tables 14 and 15 indicates that the level of meaningfulness in reading section, grammatical points, and vocabulary items of the third-year high school English textbook is more than 0.05; therefore, the mean score 
difference is not meaningful. Therefore, no significant difference exists between learners' perceptions and teachers' perceptions in terms of reading section, grammatical points, and vocabulary items of the third-year high school English textbook. The results of the Tables also shows that the level of meaningfulness in language functions section, actual activities, physical appearance, pronunciation points, and speaking section, and writing section of the third-year high school English textbook is less than 0.05. Therefore, there is a meaningful difference between learners' perceptions and teachers' perceptions in terms of language functions section, actual activities, physical appearance, pronunciation points, and speaking section, and writing section of the third-year high school English textbook.

\section{Discussion \& Conclusion}

The results of the data analysis indicated that actual activities, language functions, reading section, physical appearance, pronunciation points, speaking section, and writing section of the three high school English language textbooks which the learners rated them as being ineffective and vocabulary items, and grammatical points as effective were rated as the same by the teachers. This finding is in line with Hashemi's (2011) finding who reached the conclusion that the high school textbooks are not satisfactorily acceptable in terms of reading, pronunciation practice, practical concerns, and physical make-up. The textbooks were only "to some extent" acceptable in term of grammar presentation and practice. Moreover, the results of the data analysis indicated that no significant difference exists between learners' perceptions and teachers' perceptions in terms of actual activities, language functions section, vocabulary items, physical make-up, pronunciation points, speaking section, and writing section of the first-year high school English textbook. It can be concluded that this result confirms the null hypothesis and rejects the alternative hypothesis. The results of the data analysis also indicated that there is a meaningful difference between learners' perceptions and teachers' perceptions in terms of reading section, and grammar section of the first-year high school English textbook. It can be concluded that this result rejects the null hypothesis and confirms the alternative hypothesis. The difference in mean scores between teachers and learners in terms of reading section demonstrates that teachers' opinions toward the ineffectiveness of the reading section is stronger than those of the learners, therefore, the difference in views may stem from the fact that teachers look at the books with their critical view and the experiences they have in teaching different books by which they can analyze with more details. Moreover, the difference in mean scores between teachers and learners in terms of grammar section demonstrates that learners' opinions toward the effectiveness of the grammar section are stronger than those of the teachers'; therefore, the difference in views can be attributed to the learners' high scores in achievement tests of grammar.

Moreover, The results of the data analysis indicated that no significant difference exists between learners' and teachers' perceptions in terms of actual activities, language functions section, reading section, grammatical points, and speaking section of the second-year high school English textbook. It can be concluded that this result confirms the null hypothesis and rejects the alternative hypothesis. The results of the data analysis also indicated that there is a meaningful difference between learners' and teachers' perceptions in terms of vocabulary items, physical appearance, pronunciation points and writing section of the second-year high school English textbook. It can be concluded that this result rejects the null hypothesis and confirms the alternative hypothesis. The difference in mean scores between teachers and learners in terms of vocabulary items demonstrates that teachers' opinions toward the effectiveness of the vocabulary items are stronger than those of the learners. Moreover, the difference in mean scores between teachers and learners in terms of physical appearance, pronunciation points, and writing section demonstrates that teachers' opinions toward the ineffectiveness of the physical appearance, pronunciation points, and writing section is stronger than those of the learners', therefore, the difference in views may stem from the fact that teachers look at the books with their critical view and the experiences they have in teaching different books by which they can analyze with more details and also to the fact that learners in the second grade do not care about the physical appearance of their books much the same as the teachers, in other words teachers are more sensitive than their learners and can see that the second-year high school English textbook does not have enough quality in absorbing learners. The teachers believe that the second-year high school English textbook should have better illustrations to attract the learners. This view is in line with Dougill (1987) who argues that the physical appearance of the materials should be appealing enough to motivate the learners. This can be meant that the physical make-up of the second-year high school English textbook should be improved to motivate the learners.

Moreover, the results of the data analysis indicated that no significant difference exists between learners' perceptions and teachers' perceptions in terms of reading section, grammatical points, and vocabulary items of the third-year high school English textbook. It can be concluded that this result confirms the null hypothesis and rejects the alternative hypothesis. The results of the data analysis also indicated that there is a meaningful difference between learners' perceptions and teachers' perceptions in terms of language functions section, actual activities, physical appearance, pronunciation points, and speaking section, and writing section of the third-year high school English textbook. It can be concluded that this result rejects the null hypothesis and confirms the alternative hypothesis. The difference in mean scores between teachers and learners in terms of language functions section, actual activities, physical appearance, pronunciation points, and speaking section, and writing section demonstrates that teachers' opinions toward the ineffectiveness of the language functions section, actual activities, physical appearance, pronunciation points, and speaking section, and writing section are stronger than those of the learners, therefore, the difference in views may stem from the fact that teachers look at the books with their critical view and the experiences they have in teaching different books by which they can analyze with more details and also from the fact that, the learners in the third grade do not care about the physical appearance of their books much the same as the teachers, in other words teachers are more sensitive than their learners and can see that the third-year high school English textbook does not have enough quality in 
absorbing learners. The teachers believe that the third-year high school English textbook should have better illustrations to attract the learners. This view is supported by Griffiths (1995) who argues that interesting, attractive, and wellillustrated materials are more favorable in learners' and instructors' views.

It can be concluded that the English textbooks currently used in Iranian high schools meet neither the expectations of the learners nor the teachers within the Iranian educational system since it is grammar-based. As a result, since for Iranian EFL learners textbooks are the primary source of first-hand experience with English (Azizifar et al., 2010), high school English textbooks should be revised, and they should provide learners with opportunities to interact with the materials that motivate them to learn English (Gibbs, 1992, as cited in Rahimi and Hassani, 2012). So, the writers of the books can employ more communicative activities in order to motivate both the teachers and the learners. The findings of this study provide vital information to the textbook designers, ELT material developers and to everyone who involves in learning and teaching process especially in the field of teaching of English as a foreign language (TEFL).

\section{References}

Ansary, H. Babaii, E. (2002). Universal characteristics of EFL/ESL textbook: A step towards systematic textbook evaluation. The Internet TESL Journal, 8(2). [online] Available: http://iteslj.org/Articles/Ansary-Textbooks/

Azizifar, A. koosha, M. Lotfi, A. R. (2010). An Analytical Evaluation of Iranian High School ELT Textbooks from 1970 to the present. Procedia Social and Behavioral Sciences, 3, 36-44. http://dx.doi.org/10.1016/j.sbspro.2010.07.010

Bahumaid, S. A. (2008). TEFL Materials Evaluation: A Teacher's Perspective. Poznan Studies in Contemporary Linguistics, 44(4), 423-432. DOI: 10.2478/v10010-008-0021-z

Birjandi, P., Soheili, A., Nourozi, M., \& Mahmoodi, G.H. (2005). English Book 1. Tehran: The Iranian Textbooks Publishing Company.

Birjandi, P., Nourozi, M., \& Mahmoodi, G. (2005). English Book 2. Tehran: The Iranian Textbooks Publishing Company.

Birjandi, P., Nourozi, M., \& Mahmoodi, G. (2005). English Book 3. Tehran: The Iranian Textbooks Publishing Company.

Davison, W. F. (1975). Factors in evaluating and selecting texts for the foreign language classroom. ELT Journal, 30(4), 310-314. eltj.oxfordjournals.org/content/XXX/4/310.full.pdf

Dougill, J. (1987). Not so obvious. In L. G. Sheldon (ED.), ELT textbooks and materials: Problems in evaluation and development (ELT Documents 126) (pp.32-45). Oxford: Modern English Publications, British council.

Dubin, F., \& Olshtain, E. (1986). Course design. Developing programmers and materials for language learners.

Cambridge: Cambridge University Press.

Farrokhi, F. Saadi, M. (2013). Iranian EFL Learners' Perception with Respect to Tasks in Comparison with the Actual Content of the Textbooks. Theory and Practice in Language Studies, 3(1), 163-174. http://dx.doi.org/10.4304/tpls.3.1.163-174

Griffiths, C. (1995). Evaluating materials for teaching English to adult speakers of other languages. ELT Forum, 33(3), 153- 168.

Hashemi, R. (2011). Textbook selection and evaluation in EFL context. MA thesis. Tabriz University, Iran.

Jahangard, A. (2007). Evaluation of EFL materials taught at Iranian public high schools. The Asian EFL Journal, 9(2), 130-150.

Nunan, D. (1991). Language teaching methodology: A textbook for teachers. Hemel Hampstead: Prentice Hall.

Rahimi, M. Hassani, M. (2012).Attitude towards EFL Textbooks as a Predicator of Attitude towards Learning English as a Foreign Language. Procedia Social and Behavioral Sciences, 31, 66-72.

http://dx.doi.org/10.1016/j.sbspro.2011.12.018

Rahimi, M. Nabilou, Z. (2009). Iranian EFL Teachers' Effectiveness of Instructional Behavior in Public and Private High schools. Asia Pacific Educ, 12, 67-78. http://dx.doi.org/10.1007/s12564-010-9111-3

Rahimpour, M. Hashemi, R. (2011). Textbook Selection and Evaluation in EFL Context. World Journal of Education, 1(2), 62-68. http://dx.doi.org/10.5430/wje.v1n2p62

Razmjoo, S.A. (2007). High Schools or Private Institutes textbooks? Which fulfill communicative language teaching principles in the Iranian context? Asian EFL Journal, 9(4). 126-140.

Saadi, M. (2012). A study of Iranian EFL learners' perceptions with respect to tasks and speech acts in comparison with the actual content of the textbooks. MA thesis. Tabriz University, Iran.

Tomlinson, B., Dat, B., Masuhara, H., \& Rubdy, R. (2001). EFL courses for adults. ELT Journal, 55(1), 80-101.

Wright, T. (1987). Roles of teachers and learners. Oxford: Oxford University Press.

Yarmohammadi, L. (2002). The evaluation of pre-university textbooks. The Newsletter of the Iranian Academy of Science, 18, 70-87.

Zohrabi, M. (2011). Course Book Development and Evaluation for English for General Purposes Course. English Language Teaching, 4(2), 213-222. http://dx.doi.org/10.5539/elt.v4n2p213 


\section{Appendix A: The English Version of the Questionnaire}

The purpose of this study is to improve the quality of the first-year English textbook at high school level. For this purpose a questionnaire is prepared to obtain information about your views on the efficiency of the first-year high school English language textbook currently in use at high schools in Iran. It is not an evaluation of you as a teacher or a student, and it is not a test. There are no right or wrong answers, and all your answers are confidential. Thank you very much for taking the time to answer the questionnaire. Please answer the following questions by checking the cell which best suits your view on the given scale.

\begin{tabular}{|c|c|c|c|c|c|c|}
\hline & The questions & 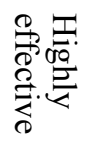 & 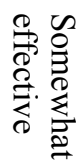 & 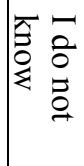 & 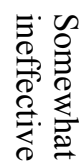 & 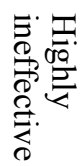 \\
\hline \multirow{5}{*}{$\begin{array}{c}\text { Actual } \\
\text { activities }\end{array}$} & $\begin{array}{l}\text { 1. How effective are the actual activities in } \\
\text { your textbook in increasing your motivation } \\
\text { to learn English? }\end{array}$ & & & & & \\
\hline & $\begin{array}{l}\text { 2. How effective are the actual activities in } \\
\text { your textbook in encouraging you to work } \\
\text { in groups? }\end{array}$ & & & & & \\
\hline & $\begin{array}{l}\text { 3. How effective are the actual activities in } \\
\text { your textbook in improving your accuracy } \\
\text { in producing pragmatically correct } \\
\text { sentences? }\end{array}$ & & & & & \\
\hline & $\begin{array}{l}\text { 4. How effective are the actual activities in } \\
\text { your textbook in improving your fluency in } \\
\text { speaking English? }\end{array}$ & & & & & \\
\hline & $\begin{array}{l}\text { 5. How effective are the actual activities in } \\
\text { your textbook in improving your language } \\
\text { skills (reading, writing, listening, } \\
\text { speaking)? }\end{array}$ & & & & & \\
\hline \multirow{5}{*}{$\begin{array}{l}\text { Language } \\
\text { functions } \\
\text { section }\end{array}$} & $\begin{array}{l}\text { 6. How effective is the language functions } \\
\text { section of your textbook in increasing your } \\
\text { motivation to speak English? }\end{array}$ & & & & & \\
\hline & $\begin{array}{l}\text { 7. How effective are the dialogues in the } \\
\text { language functions section of your textbook } \\
\text { in helping you to speak appropriately (the } \\
\text { same way native speakers of English do)? }\end{array}$ & & & & & \\
\hline & $\begin{array}{l}\text { 8. How effective are the dialogues in the } \\
\text { language functions section of your textbook } \\
\text { in fulfilling your daily needs (for reading } \\
\text { stories, watching movies, etc.)? }\end{array}$ & & & & & \\
\hline & $\begin{array}{l}\text { 9. How effective is the language functions } \\
\text { section of your textbook in providing you } \\
\text { with the opportunity to practice the } \\
\text { dialogues in this section? }\end{array}$ & & & & & \\
\hline & $\begin{array}{l}\text { 10. How effective is your textbook in repeating } \\
\text { and reinforcing language functions in } \\
\text { subsequent lessons? }\end{array}$ & & & & & \\
\hline \multirow{5}{*}{ Reading texts } & $\begin{array}{l}\text { 11. How effective are the reading texts in your } \\
\text { textbook in making language learning } \\
\text { enjoyable? }\end{array}$ & & & & & \\
\hline & $\begin{array}{l}\text { 12. How effective are the reading texts in your } \\
\text { textbook in increasing your motivation to } \\
\text { learn English? }\end{array}$ & & & & & \\
\hline & $\begin{array}{l}\text { 13. How effective are the reading texts in your } \\
\text { textbook in improving your vocabulary } \\
\text { knowledge? }\end{array}$ & & & & & \\
\hline & $\begin{array}{l}\text { 14. How effective are the reading texts in your } \\
\text { textbook in improving your language skills } \\
\text { (reading, writing, listening, speaking)? }\end{array}$ & & & & & \\
\hline & $\begin{array}{l}\text { 15. How effective are the reading texts in your } \\
\text { textbook in engaging you in learning about } \\
\text { the target language culture? }\end{array}$ & & & & & \\
\hline
\end{tabular}




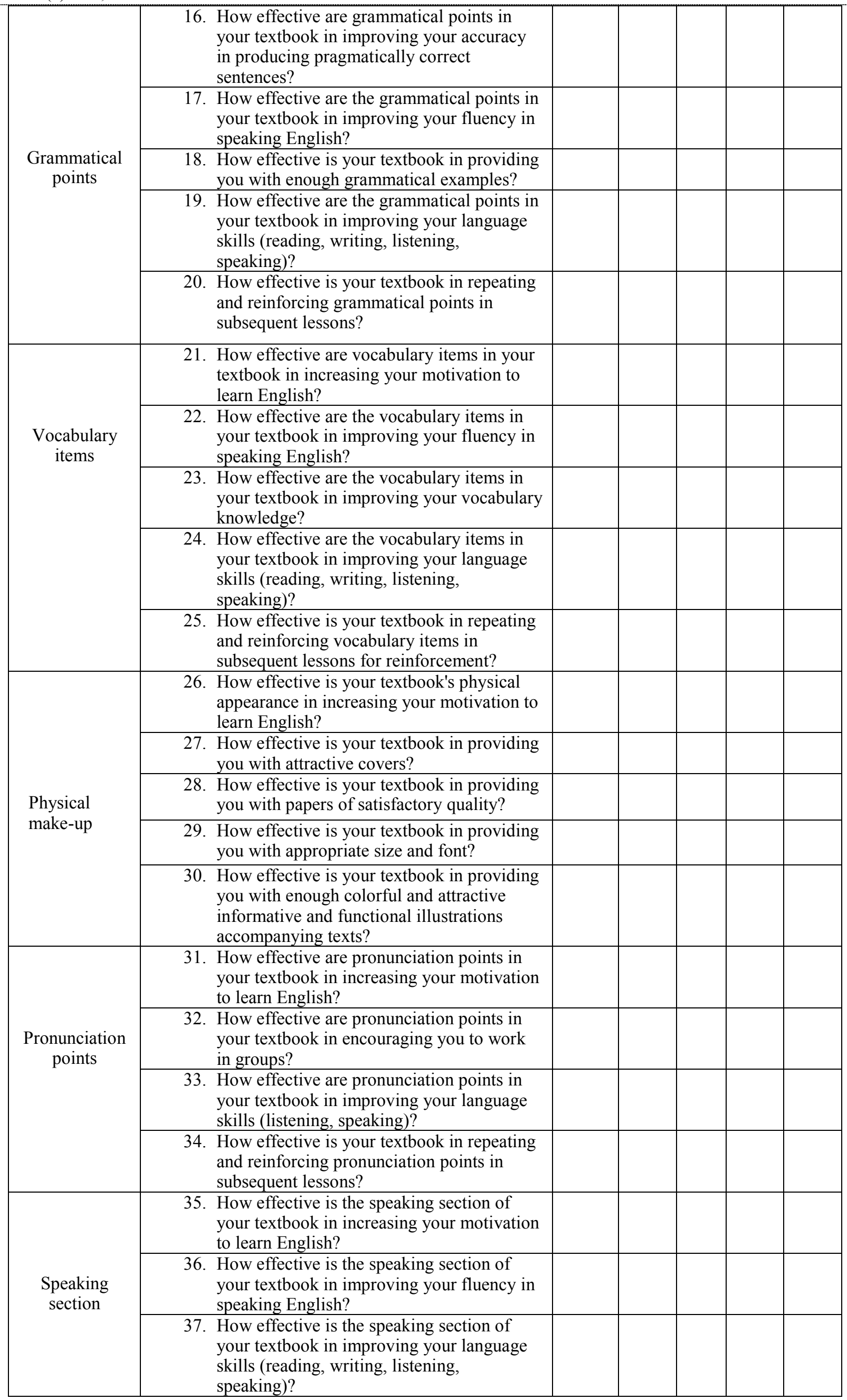




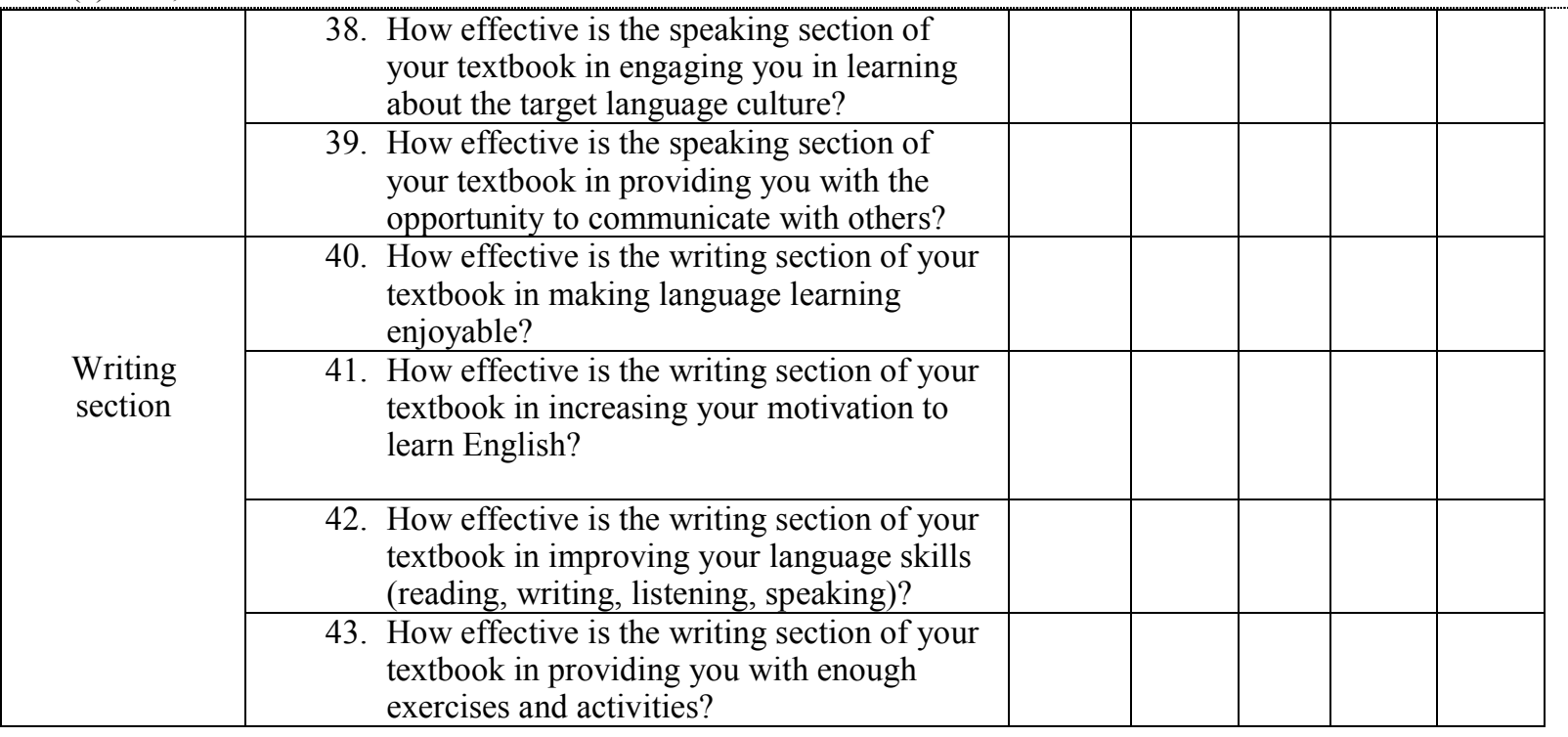

Many thanks for the time that you kindly spent to fill out this questionnaire.

\section{Appendix B: Interview Questions}

The following questions were used in the interviews:

1. Do these textbooks provide you with an opportunity to boost your motivation in learning English?

2. What is/are the main problem(s) with the English textbooks currently used in Iranian high schools?

3. To what extent the textbooks include all four language skills (speaking, listening, reading, and writing)?

4. Are the language skills being emphasized equally?

5. What aims would you like to achieve at the end of your education?

6. What are your suggestions in making the textbooks more interesting?

7. How can Ministry of Education make the textbooks more interesting? 